\title{
THE LOCAL GOVERNMENT STRATEGY TO INCREASE COVERAGE FOR EXCLUSIVE BREASTFEEDING IN BOALEMO DISTRICT
}

\author{
Robert Pauweni \\ Study Program of Master in Administrative Science, Universitas Negeri Gorontalo, Gorontalo, Indonesia \\ *Corresponding Author: tika_aknis@yahoo.com
}

\begin{abstract}
This research aims at finding out and describing 1) the local government strategy to increase coverage for exclusive breastfeeding in Boalemo District and 2) factors supporting and hindering the strategy development of local government to increase coverage for exclusive breastfeeding in Boalemo district. This research applies qualitative method. Data collection uses interview, observation, and documentation. Based on the findings, it concludes that there are several things to be done by the local government in increasing coverage for exclusive breastfeeding, including enacting the local regulation for exclusive breastfeeding program, deciding the target areas, systematically implementing exclusive breastfeeding program, and supervising the program. On the other hand, factors supporting and hindering the coverage for exclusive breastfeeding program are policy support, budget availability, the healthcare workers, knowledge factor, health service facilities, cultural factor, and promotion on infant formula.
\end{abstract}

Keywords: Local Government Strategy; The Increasing of Exclusive Breastfeeding.

\section{INTRODUCTION}

The success of healthcare development is immensely affected by precise approach, policy, and program strategy along with having a definite target. The efforts in healthcare developments are performed in integrated manners consisting of planning, implementing, supervising, and evaluating. These are carried out to ensure the existing resources are utilized effectively and efficiently. The target is also focused on the family, in the revival of the "Family Approach". The support of accurate and prompt health data and information is considered necessary to determine policies and strategies for proper healthcare development.

The quality of health service in fulfilling the basic needs of society is a form of public services that needs to be complied with by the local government. Healthcare is a complex service since all aspects such as the facilities, drinking water, hygiene, and environmental sanitation must meet the health standards. The improvement of human resource quality is supposed to be started as early as possible, and one of the most important factors is the breastfeeding. Breastmilk is an ideal nutrient for infant growth, increases intelligence, strengthens the immune system, and reduces the risk of the spread of infectious diseases. These benefits are gained through exclusive breastfeeding at the age of the first six months (Alves et al., 2018; Kramer \& Kakuma, 2012; Riordan, 2010). The first total of 1000 days comprises 270 days of pregnancy period and 730 days of the sensitive period for the baby's first life. Complete and balanced nutrition for infants gives permanent results that will be unalterable later in life. Malnutrition has negatively affected their physical growth, mental development, and intelligence. Furthermore, when they are entering adulthood, they tend to have the unideal physical size and uncompetitive working quality. As a consequence, the economic productivity of the nation will be low either from individual or collective.

The Innocenti declaration in Florence, Italy, in 1990 mandated the importance of campaigning breastmilk in an attempt to "protect, promote, and support breastfeeding." The gold standard of feeding infants and toddlers has also been established by the Indonesian Ministry of Health (2017a). They are namely: 1) breastfeeding within 1 hour after giving birth (early initiation of breastfeeding or EIB); 2) exclusive breastfeeding for the first six months; 3) complementary feeding at the age of 6 months; 4) extended breastfeeding until the baby is 24 months or more. In addition, breastfeeding is free compared to other complementary food that should be added to family expenses.

The result of monitoring of nutrition status in 2016 in Indonesian Health Profile (Ministry of Health, 2017b) revealed that the national average percentage of newborns who received the EIB in 2016 was 51.9\% consisting of $42.7 \%$ newborns receiving EIB less than 1 hour after birth, and 9.2\% newborns receiving EIB within 1 hour or more after birth. DKI Jakarta province made up the highest percentage (73\%), and Bengkulu province made up the least (16\%). Apart from that, the national average from the percentage of 0-5-month-old babies who received exclusive breastfeeding was $54 \%$. The following table shows the comparison in some provinces. 
Table 1.1. Coverage of Exclusive Breastfeeding for 0-5-month-old babies Provinces (selected) 2016

\begin{tabular}{|l|c|c|}
\hline \multicolumn{1}{|c|}{ Provinsi } & Cakupan ASI eksklusif (\%) & Peringkat \\
\hline Nusa Tenggara Timur & 79.9 & 1 \\
\hline Papua & 76.2 & 2 \\
\hline NTB & 72.8 & 3 \\
\hline Sulawesi Barat & 62.7 & 6 \\
\hline Maluku & 61.3 & 7 \\
\hline Papua Barat & 51.9 & 17 \\
\hline Kalimantan Utara & 51.9 & 19 \\
\hline Maluku Utara & 49.5 & 28 \\
\hline Sulawesi Tengah & 43.3 & 34 \\
\hline Gorontalo & 32.3 & \\
\hline
\end{tabular}

Sumber: Profil Kesehatan Indonesia Tahun 2016;

Kementerian Kesehatan RI 2017

The table above illustrates that the three provinces used in this research are in the top-ranked (NTT, Papua, and NTB). West Sulawesi and Maluku are still in the top ten, whereas Gorontalo made up the bottom position with 32,3\%.

Picture 1.1: Coverage of Exclusive Breastfeeding in Gorontalo Province Based on Districts and City in 2016-2018.

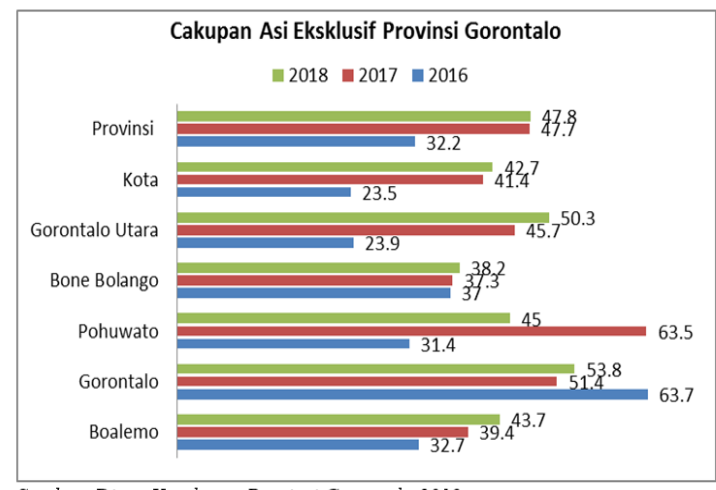

Sumber: Dinas Kesehatan Provinsi Gorontalo 2019

Based on the picture above, Boalemo District, North Gorontalo District, and Gorontalo City made a significant increase. Bone Bolango District rose gradually, whereas Gorontalo District and Pohuwato District were quite volatile. Boalemo District, as a research area, has several uniqueness related to the ratio of the number of health facilities with a large number of remote and isolated villages. This obviously has an effect on the level of accessibility and acceptability from society towards the health service. The actual condition of health service facilities in Boalemo District is consisted of two units, namely, the class C of Tani and Nelayan Regional Public Hospital, situated on the pivot road of Trans Sulawesi, Lamu Village, Tilamuta Subdistrict, and the class D of Pratama Regional Hospital located in the pivot road of Trans Sulawesi, Tangkobu Village, Paguyaman Subdistrict. This hospital had been in the preparation stage and had not been operated yet until this proposal was composed. 
Table 1.3: Coverage for Exclusive Breastfeeding in Boalemo District Based on the Public Health Center Locations from 2016-2018.

\begin{tabular}{|c|c|c|c|c|c|c|c|c|c|c|}
\hline \multirow[b]{2}{*}{ No } & \multirow[b]{2}{*}{ Lokasi Puskesmas } & \multicolumn{3}{|c|}{ Tahun 2016} & \multicolumn{3}{|c|}{ Tahun 2017} & \multicolumn{3}{|c|}{ Tahun 2018} \\
\hline & & $\begin{array}{c}\text { Jumlah } \\
\text { Bayi }\end{array}$ & $\begin{array}{c}\text { ASI } \\
\text { eksklusif }\end{array}$ & Cakupan & $\begin{array}{c}\text { Jumlah } \\
\text { Bayi }\end{array}$ & $\begin{array}{c}\text { ASI } \\
\text { eksklusif }\end{array}$ & Cakupan & $\begin{array}{c}\text { Jumlah } \\
\text { Bayi }\end{array}$ & $\begin{array}{c}\text { ASI } \\
\text { eksklusif }\end{array}$ & Cakupan \\
\hline 1 & Pagyxaman Pantai & 69 & 42 & 61 & 81 & 17 & 21 & 15 & 12 & 83 \\
\hline 2 & Paguyaman & 221 & 122 & 55 & 161 & 52 & 32 & 109 & 21 & 20 \\
\hline 3 & Berlian & 78 & 34 & 44 & 67 & 19 & 28 & 37 & 13 & 35 \\
\hline 4 & Bongo Nol & 179 & 85 & 47 & 97 & 34 & 35 & 71 & 18 & 25 \\
\hline 5 & Bongo Dua & 191 & 71 & 37 & 187 & 114 & 61 & 62 & 34 & 55 \\
\hline 6 & Saritani & 119 & 72 & 61 & 76 & 33 & 43 & 58 & 35 & 60 \\
\hline 7 & Dulupi & 42 & 13 & 31 & 85 & 22 & 26 & 33 & 14 & 42 \\
\hline 8 & Pangi & 117 & 64 & 55 & 87 & 12 & 14 & 59 & 34 & 58 \\
\hline 9 & Tilamuta & 336 & 197 & 59 & 304 & 166 & 55 & 65 & 46 & 71 \\
\hline 10 & Botumeito & 249 & 112 & 45 & 157 & 58 & 37 & 81 & 58 & 72 \\
\hline \multirow[t]{2}{*}{11} & Mananggu & 184 & 100 & 54 & 133 & 117 & 88 & 43 & 32 & 74 \\
\hline & Total & 1785 & 912 & 549 & 1435 & 644 & 440 & 633 & 317 & 595 \\
\hline & Rata-rata Kab & & & 49,90 & & & 40 & & & 54,09 \\
\hline
\end{tabular}

Based on the locations of the public health centers in Boalemo District, the highest coverage for exclusive breastfeeding was Paguyaman Pantai and Saritani in 2016 (index 61), Mananggu in 2017 (88), and Paguyaman Pantai in 2018 (83). On the contrary, the lowest coverage was Dulupi (31), Pangi (14), and Bongo Nol (25) from 2016 to 2018, respectively. In the same period, Public Health Center (Puskesmas) Bongo Nol demonstrated that the below average of exclusive breastfeeding coverage was 47 (average index of 49.90), 35 (40), and 25 (54.09). Whereas the number of babies treated at the local health center and exclusive breastfeeding approach experienced a continuous decline. This definitely has become a serious problem for the local community and government. In many global cases and remote areas in Indonesia, the low coverage of exclusive breastfeeding does take part in the occurrence of malnutrition, susceptible, stunting, dehydration, pneumonia, and other degenerative diseases, as well as the higher risk of death.

\section{METHODOLOGY OF RESEARCH}

This research applies qualitative research with techniques of data collection consisting of a) observation, b) in-depth interview analysis, c) documentation study, and d) Focus Group Discussion.

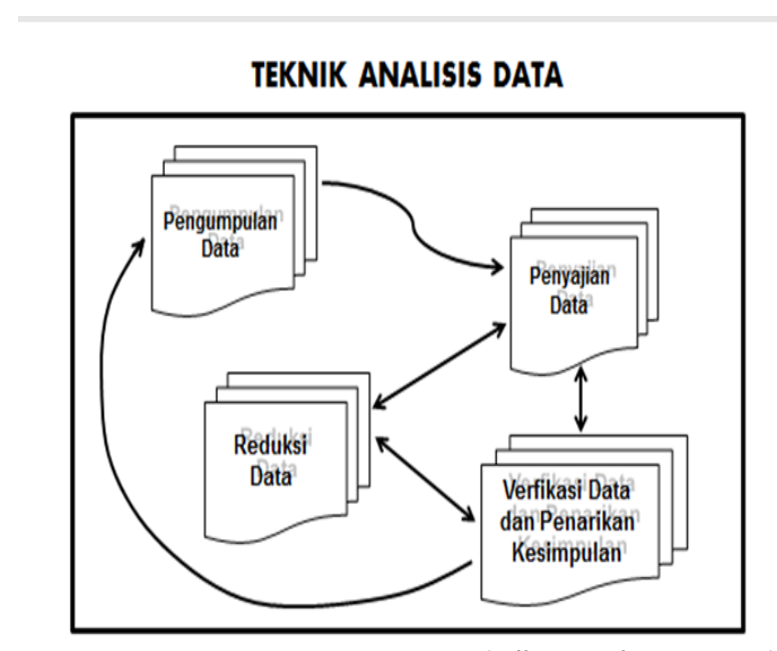

Gambar 3.1: Analisis Model Interaktif (Miles \& Huberman, 1992)

In this research, the data instruments are in the form of observation and interview formats distributed to respondents either in a direct interview or structured interview way. The research site covers the whole unit of the health office, hospital, public health centers, Integrated Healthcare Center, local government, community leaders, and women in their exclusive breastfeeding phase. Below are the eleven public health center locations in Boalemo District: 


$\begin{array}{clcl}\text { I } & \text { Paguxaman Pantai } & \text { vii } & \text { Dulupi } \\ \text { Ii } & \text { Paguyaman } & \text { viii } & \text { Pangi } \\ \text { Iii } & \text { Berlian } & \text { ix } & \text { Tilamuta } \\ \text { Iv } & \text { Bongo Nol } & \text { x } & \text { Botumoito } \\ \text { V } & \text { Bongo Dua } & \text { xi } & \text { Mananggu } \\ \text { Vi } & \text { Saritani } & & \end{array}$

\section{FINDINGS}

The local government strategy to increase coverage for exclusive breastfeeding in Boalemo District is through a package of policies that has become an innovation of the local government named "GEMAR DAMAI." It is movement care for pregnant and lactating women and aims at setting the local regulations to govern the exclusive breastfeeding program, establishing target areas, systematically implementing exclusive breastfeeding programs, and supervising the program. This innovation is also used as a counter-attack against the incessant promotion of infant formula.

The Gemar Damai program mandates the local government of Boalemo District to: first, enacting local regulation of exclusive breastfeeding; second, establishing target areas for all local health institutions to be responsible for the increasing coverage of exclusive breastfeeding; third, systematically implementing exclusive breastfeeding program; fourth, supervising the exclusive breastfeeding program.

\section{DISCUSSION}

The Gemar Damai program mandates the local government of Boalemo District to: first, enacting local regulation of exclusive breastfeeding; second, deciding target areas for all local apparatuses to be responsible for the increasing coverage of exclusive breastfeeding; third, systematically implementing exclusive breastfeeding program; fourth, supervising the exclusive breastfeeding program.

\section{Local Regulation Enactment on Exclusive Breastfeeding}

The local regulation on exclusive breastfeeding in Boalemo District is considered necessary because it has a direct effect on reducing obstacles from internal family and community, add more human resources, and provide lactation facilities in both government and nongovernment institutions.

Enacting the exclusive breastfeeding program gives the community to play a role in accessing and conducting social control toward policies and program activities that include budgeting on the exclusive breastfeeding program. Social control is intended as active participation from the local government to, directly and indirectly, oversee the process of implementation and transparent local governance (Tahir 2011).

\section{Regent's Instruction in deciding target areas for all village apparatuses to be responsible for increasing coverage of exclusive breastfeeding}

The regent's instruction to have supervision and guidance from village apparatuses are in compliance with the public health office strategic plans of 2018-2022. One of the points is to encourage the local community to work in synergy with all sectors, including the village apparatuses who responsible for the village itself. With the support from local government, the village and the working partner will be able to generate innovative programs, enhance apparatuses capacity (candidates of Integrated Healthcare Center), and conduct creative activities to increase coverage for exclusive breastfeeding by utilizing village funds.

\section{Regent's Instruction to have a systematic implementation on exclusive breastfeeding program}

Regent's instruction outlined in regent regulation is crucial to conduct massive, structured, and systematic exclusive breastfeeding program. This instruction clearly regulates the facilities such as lactation room, storage for breast milk, and other facilities provided in government offices, nonprofit organizations, private business entities and schools.

\section{Supervision on exclusive breastfeeding program}

The success of the exclusive breastfeeding program is underlied with a structured supervision program that protects from all interfering and hindering influences. The supervision must be optimally performed through approaching all society elements in order to jointly supervise and ensure the exclusive breastfeeding program as expected.

\section{CONCLUSION}

Based on the previous findings and discussions, it can be concluded that:

1. The local government strategy to increase coverage for exclusive breastfeeding in Boalemo District is through a package of policies called "GEMAR DAMAI" or movement care for pregnant and lactating women. The movement consists of enacting the local regulation that governs the exclusive breastfeeding program, establishing 
target areas, systematically implementing exclusive breastfeeding program, and supervising the program. This innovation is also used as a counter-attack against the incessant promotion of infant formula.

2. Supporting and hindering Factors to increase coverage for exclusive breastfeeding encompass policy support, budget availability, knowledge factor, health service facilities, cultural factor, and promotion on infant formula

3. SWOT analysis shows that the effort in increasing coverage for exclusive breastfeeding in Boalemo District lies in the first quadrant (positive - positive). The institutional or organizational environment is in stable condition in terms of internal and external aspects.

\section{SUGGESTION}

Based on the above conclusions, the implications of policy and suggestion are as follows:

1. Local regulation enactment is absolutely important to increase coverage for exclusive breastfeeding in Boalemo District. The low coverage than other districts and city in Gorontalo Province should make Boalemo District receive more attention and priority from the Government.

2. Government and the regional representative council should set budgetary policies. For instance, 5-7\% of local government budget will be allocated to increase coverage for exclusive breastfeeding. This is in line with Minister of Health decree number HK.02.02/Menkes/52/2015 to encourage villages to allocate and utilize their funds of at least $10 \%$ for human resource health efforts as outlined in the village regulation

3. The government should instruct all village apparatuses to be responsible for the increase of exclusive breastfeeding in Boalemo District.

\section{REFERENCES}

Abdul Wahab, Solichin. 2017. Analisis Kebijakan: Dari Formulasi ke Penyusunan Model-model Implementasi Kebijakan Publik. Cetakan Keenam. Jakarta. Penerbit Bumi Aksara

Achmadi, U.F. 2013. Kesehatan Masyarakat Teori dan Aplikasi. Jakarta: Raja GrafindoPersada

Alison, GT. 1997. Public and Private Management; Are they fundamentally alike in all unimportant respects?Dalam Classics of Public Administration diedit oleh Shafritz J \& A.C Hyde. Pacific Grove. CA. California: Brooks/Cole Publishing Company

Alves, Carvalho, Lopes, Silva, Teixeira. 2018. Nurses Contributions to the Promotion of Exclusive Breastfeeding. doi:10.15253/2175-6783.20181933072 www.revistarene.ufc.br

Anasiru, MA, Ruhmayanti NA, Imale S.2017.Gambaran Pengetahuan ASI Eksklusif pada Ibu Menyusui di Desa Tabongo Timur Kabupaten Gorontalo. Health and Nutritions Journal Volume III / Nomor 2 / 2017p - ISSN: 2407-8484. e- ISSN: 2549-7618

Bachri, B. S. 2010. Meyakinkan Validitas Data Melalui Triangulasi pada Penelitian Kualitatif. Universitas Negeri Surabaya. Surabaya

BPS. 2019. Kabupaten Boalemo Dalam Angka Tahun 2019. Badan Pusat StatistikKabupatenBoalemo

BPS. 2019. Indikator Kesejahteraan Rakyat Kabupaten Boalemo Tahun 2018. Badan Pusat Statistik Kabupaten Boalemo

Cameron \& Quinn. 1999. Diagnosing and Changing Organizational Culture Based On the Competing Values Framework, Addison Wesley Mass: Reading

Dinas Kesehatan Kabupaten Boalemo. 2019. Profil Kesehatan Kabupaten Boalemo Tahun 2019. [Unpublished]

Dinas Kesehatan Kabupaten Boalemo. 2017. Rencana Strategis Dinas Kesehatan Kabupaten Boalemo 2017-2022.

Donovan, F \& AC Jackson. 1991. Managing Human Service Organizations. NY. New York: Prenctice-Hall

Dye, Thomas R. 2016. Understanding Public Policy. $15^{\text {th }}$ Edition. New Jersey US: Pearson Publisher

Ghani, A and Lockhart, C. 2008. Fixing Failed States: A Framework for Rebuilding A Fractured World. Oxford US: University Press

Ginting, dkk. 2013. Pengaruh Karakteristik Faktor Internal dan Eksternal Ibu terhadap Penerapan MP-ASI Dini pada Usia< 6 Bulan di Wilayah Kerja Puskesmas Barujahe Kabupaten Karo Provinsi Sumatra Utara.http://respository.unpat.ac.id.

Grant, Robert M. (1999). Contemporary Strategy Analysis; Concept, Techniques, Applications. Jakarta: Penerbit Erlangga

Grindle, M. 1980. Politics and Policy Implementation in the Third World. New Jersey US: Princeton University Press Hasibuan, M. 2001. Manajemen Sumber Daya Manusia. Jakarta: PT. Bumi Aksara

Ilato, R. 2017. Capacitiy Building: Pemerintah Daerah Menuju Good Governance. Gorontalo: Ideas Publishing Ismail, S, 2012. Manajemen Strategik, Bandung: Erlangga

Joyce, P. 2015. Strategic Management in the Public Sector. NY. New York: Routledge Taylor \& Francis Group Publisher.

Keban. YT. 2014. Administrasi Publik: Konsep, Teori dan Isu. EdisiKetiga. Yogyakarta: Penerbit Gava Media Kementerian Kesehatan RI. 2018. Data dan Informasi Profil Kesehatan Indonesia Tahun 2018. Maret 2019. Kementerian Kesehatan RI. 2017a. Pedoman Penyelenggaraan Pekan ASI Sedunia Tahun 2017. Kemenkes RI Kementerian Kesehatan RI. 2017b. Profil Kesehatan Indonesia Tahun 2016

Kementerian Kesehatan RI. 2017c. Data Dasar Puskesmas Gorontalo-Kondisi Desember 2016. Provinsi Gorontalo 
Knoepfel, Peter et al. 2007. Public Policy Analysis. The Policy Press. Bristol: University of Bristol Kramer, M. S., and Kakuma, R. 2012. Optimal duration of exclusive breastfeeding. The Cochrane Library

$\mathrm{Ku}, \mathrm{CM}$, \& Chow, SK. 2010. Factors Influencing the Practice of Exclusive Breastfeeding among Hong Kong Chinese Women: A Questionnaire Survey. Journal of clinical nursing, 19(17-18), 2434-2445

Kumar, S. Adhis, VS \&Deoki N. 2014. Introduction to Strategic Management and Leadership for Health Professionals. Indian Journal of Community Medicine. 2014 Jan-Mar; 39(1): 13-16. doi: 10.4103/09700218.126345

Kurniawan, B. 2013. Determinan Keberhasilan Pemberian Air Susu Ibu Eksklusif. Jurnal Kedokteran Brawijaya 2013; 27:4.

Lowry AW, Bhakta, Kushal Y, Nag Pratip K. 2014. Buku Saku Pediatri dan Neonatologi. Jakarta. Penerbit Buku Kedokteran EGC

Mahmudi. 2010. Manajemen Kinerja Sektor Publik. Yogyakarta: UPP STIM YKPN

Marrus, K. 2002. Desain Penelitian Manajemen Strategik. Jakarta; Rajawali Press

Moleong, L.J. 2012. Metodologi Penelitian Kualitatif. Bandung: PT Remaja Rosdakarya

Naisbit, J. 2006. Mindset! Reset Your Thinking and See The Future. New York. NY: Collins.

Nawawi, H. 2005. Manajemen Strategik. Yogyakarta: Gadjah Mada Press.

Permadi, dkk. 2017. Early Breastfeeding Initiation and Exclusive Breastfeeding as Risk Factors on Stunting Children 6-24 Months-Old. Jurnal Penelitian Gizi dan Makanan. Juni 2016. Vol 39 (1) 9-14.

Pigors, P \& CA Myeers. 1973. Personal Administration: a point of view and a method. Seventh edition. International Student edition. Tokyo: McGraw-Hill Kogakhusha Ltd.

Pokhrelet all. 2014. Potential Economic Impacts from Improving Breastfeeding Rates in the UK. Published by group.bmj.com

Pramukti, I. Hill, M. Mohammad Isa, NB. 2014. Mother and Family's View on Exclusive Breastfeeding in Developing Country. Jurnal Metasynthesis of Mother and Family's View on Exclusive Breastfeeding. II (3) Desember 2014:179-190

Riordan, J. \& Wambach, K. 2010. Breastfeeding and Human Lactation. Fourth Edition. Sudbury: Jones and Bartlett Publisher

Robert, BL. 1984. Competitive Strategic Management. Englewood Cliffs. NJ. New Jersey: Prentice-Hall

Salusu, J. 2006.Pengambilan Keputusan Strategik untuk Organisasi Publik dan Non-Profit. Jakarta: Grasindo

Saxena, PK. 2009. Principles of Management; A Modern Approach. New Delhi: Global India Publications PVT Ltd

Shafritz, J.M \& E.W. Russel. 1997. Introducing Public Administration. NY. New York: Addison-Wesley Educational Publisher Inc. Chapter 1

Siagian, S.P. 2005. Manajemen Strategik. Jakarta: Penerbit Bumi Aksara

Stoner, J.A.F. 1978. Management. Englewood Cliffs. NJ. New Jersey: Prentice-Hall

Subarsono, AG. 2011. Analisis Kebijakan Publik. Yogyakarta: Pustaka Pelajar

Sugiyono. 2011. Metode Penelitian Kuantitatif Kualitatif dan R\&D. Bandung: Penerbit Alfabeta

Syafiee, IK. 2009. Pengantar Ilmu Pemerintahan. Edisi Kelima. Bandung: Penerbit Refika Aditama.

Tahir, Arifin. 2011. Kebijakan Publik dan Transparansi Penyelenggaraan Pemerintahan Daerah. Jakarta. Pustaka Indonesia Press

Tahir, Arifin. 2010, Analisis Implementasi Kebijakan Transparansi Penyelenggaraan Pemerintahan Kota Gorontalo. Disertasi, Universitas Negeri Makassar

Terry, GR. \& Rue, LW. 2010. Dasar-dasarManajemen. Penerjemah GA. Ticoalu. Cetakan ke-9. Edisi Bahasa Indonesia. Jakarta: BumiAksara

Van Meter, D. \& Can Horn, C. 1975. The Policy Implementation Process: A Conceptual Framework. Administration and Society, Vol. 6 No. 4. February

Wheelen, TL., \& Hunger, JD. 2010.Strategic Management and Business Policy: Achieving Sustainability, $12^{\text {th }}$ Edition, Pearson, Prentice Hall, Upper Sadle River. New Jersey

World Health Organization WHO. 2011. Exclusive Breastfeeding for Six Months Best for Babies Everywhere.https://www.who.int/mediacentre/news/statements/2011/breastfeeding_20110115/en/

Wibowo, M. 2016. Dukungan Informasi bagi Ibu Menyusui dalam Memberikan ASI Eksklusif di Kecamatan Gondokusuman, Yogyakarta, Jurnal Kesehatan Masyarakat (KEMAS) 11 (2) (2016) ISSN 1858-1196 